\title{
Successful management of uterine prolapse during pregnancy with vaginal pessary: a case report
}

\author{
Gebelikte uterin prolapsusun vajinal pesser ile başarll yönetimi; vaka sunumu
}

Esra Esim Büyükbayrak, Gülden Yılmazer, Ayşe Gül Özyapı, Bülent Kars, Ayşe Yasemin Karageyim Karşıdağ, Cem Turan

Dr. Lütfi Kırdar Kartal Education and Research Hospital, Obstetrics Department, Istanbul, Turkey

\section{Abstract}

We present a case of uterine prolapse complicating a second trimester pregnancy which was managed successfully with a vaginal pessary.

Case: A 19 year-old primigravid woman referred to the obstetric emergency unit at the 16th week of gestation complaining of uterine prolapse. A silicone ring-shaped middle-size vaginal pessary was placed into the vagina. On each control visit, when the vaginal pessary was removed, the uterine prolapse still persisted until birth. The patient gave birth at $38^{\text {th }}$ week by spontaneous vaginal delivery to a healthy baby. After birth, with uterine contractions, uterine prolapse regressed progressively.

Conclusion: The management and treatment of uterine prolapse in pregnancy should be individualized depending on the patient's preference. A vaginal pessary may be helpful to avoid complications of this condition and should be considered during patient counseling.

(J Turkish-German Gynecol Assoc 2010; 11: 105-6)

Key words: Uterine prolapse, pregnancy, vaginal pessary

Received: 7 July, 2009

Accepted: 13 October, 2009

\section{Introduction}

Uterine prolapse during pregnancy is a rare condition with an estimated incidence of 1 per 10,000-15,000 deliveries (1). Complications of this condition are patient discomfort, cervical desiccation and ulceration, urinary tract infection, acute urinary retention, abortion, preterm labor, fetal and maternal sepsis, and maternal death (2). The management varies from a conservative approach to laparoscopic treatment (3).

A vaginal pessary for uterine prolapse during pregnancy was first used in 1949. There are various shapes and sizes of pessaries. The silicone coated ring pessary is amenable for selfremoval and insertion by the patient (4).

We present a case of uterine prolapse complicating a second trimester pregnancy which was managed successfully with a vaginal pessary.

\section{Case}

A 19 year-old primigravid woman was referred to the obstetric emergency unit at the $16^{\text {th }}$ week of gestation complaining of uterine prolapse. There was no history of pelvic trauma, stress urinary incontinence or uterine prolapse before pregnancy. On pelvic examination the cervical os was closed and the entire cervix was lying outside of the vulva (Figure 1). The cervix was enlarged, edematous and ulcerated but not desiccated.

\section{Özet}

Gebeliğin ikinci trimesterinde izlenen uterin prolapsus durumunun vajinal pesser ile başarıyla yönetildiği bir olgu sunulmuştur.

Vaka: 19 yaşında, 16 haftalık gebeliği bulunan primigavid hasta kliniğimiz obstetrik polikliniğine rahim sarkması sikâyetiyle başvurmustur. Orta boy, yuvarlak, silikon pesser vajene yerleştirilerek prolapsus redükte edilmiştir. Her kontrolde vajinal pesser çıkarıldığında prolapsus halinin doğuma kadar sebat ettiği izlenmiştir. 38'inci gebelik haftasında spontan vajinal doğum ile sağlıklı bir bebek doğurtulmuştur. Doğum sonrasında uterin kontraksiyonlarla prolapsus hali progresif olarak gerilemiştir.

Sonuç: Gebelikte gelişen uterin prolapsusun yönetiminde ve komplikasyonlarından korunmada vajinal pesser uygulaması faydalıdır ve hasta değerlendirilirken göz önünde tutulmalıdır.

(J Turkish-German Gynecol Assoc 2010; 11: 105-6)

Anahtar kelimeler: Uterin prolapsus, gebelik, vajinal pesser

Geliş Tarihi: 07 Temmuz 2009

Kabul Tarihi: 13 Ekim 2009

The obstetric ultrasonography revealed a 16 weeks live, apparently normal fetus with a normal amniotic fluid index. A Papanicolaou smear test was taken on her first visit and reported inflammatory changes.

We recommended antibiotherapy (amoxicillin clavulonate treatment for seven days) for cervicovaginal infection and a vaginal pessary to reduce prolapsed uterus. Bed rest was not recommended and the patient was told to continue her routine daily activities. A silicone ring-shaped middle-size vaginal pessary was placed in the vagina and the patient was taught how to place the vaginal pessary herself. After insertion of the pessary, the cervix remained totally intravaginal and there was no urinary retention complaint by the patient (Figure 2). The patient was then controlled weekly and at each control visit the vaginal pessary was removed, disinfected with baticon and replaced in the vagina until the $20^{\text {th }}$ week. The patient was followed up monthly until the $32^{\text {nd }}$ week, twice a month until the $36^{\text {th }}$ week and then weekly until birth. The antepartum follow-up was unremarkable and no further complications occurred during pregnancy. The patient adjusted herself to the pessary perfectly and there was no complaint of the pessary falling out. There was no vaginal ulceration due to vaginal pessary usage and cervical ulceration healed because the cervix remained intravaginal with the vaginal pessary. On each control visit, when we took the vaginal pessary out, uterine prolapse still persisted up to birth. 


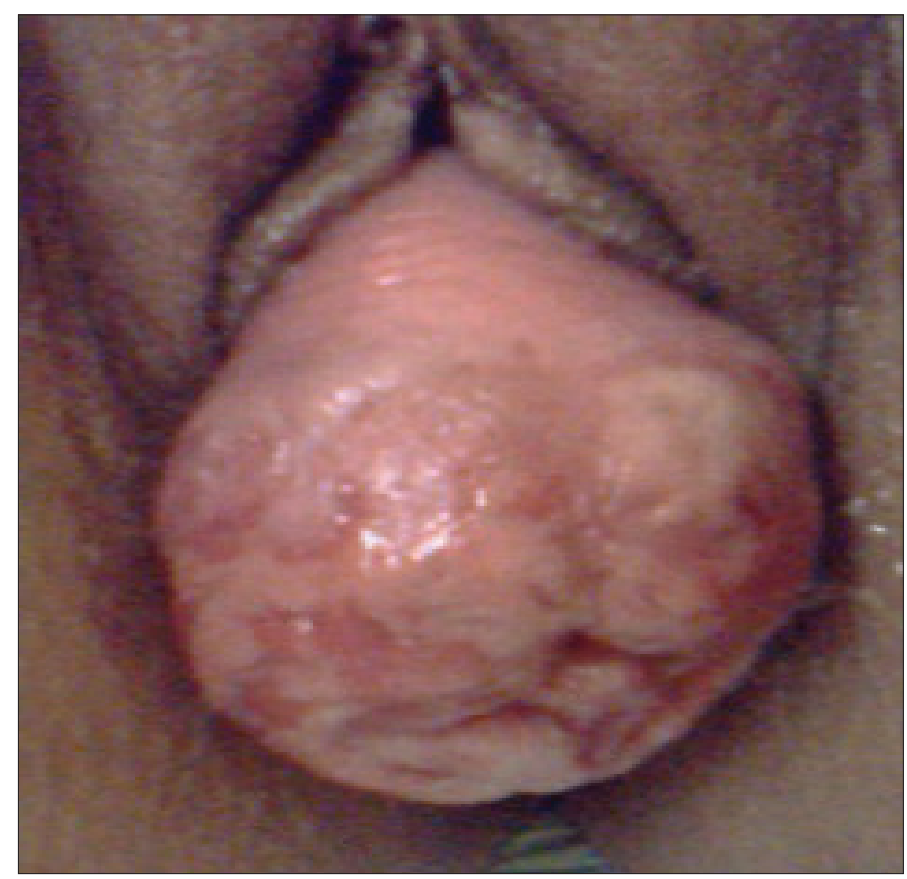

Figure 1. Uterine prolapsus in pregnancy

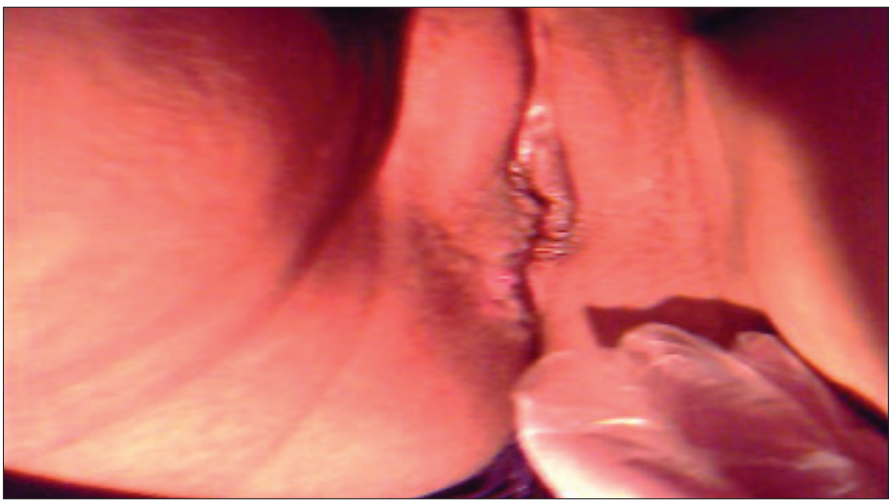

Figure 2. Cervix remained intravaginal after insertion of vaginal pessary

The patient gave birth at $38^{\text {th }}$ week by spontanous vaginal delivery to a healthy $3200 \mathrm{gr}, 50 \mathrm{~cm}$ baby with Apgar scores of 8 and 10. After birth, with uterine contractions, the uterine prolapse regressed progressively. On the first postpartum day, the uterine prolapse was completely resolved and the patient was discharged on the second postpartum day. The puerperial period was uneventful. A control examination at the second postpartum month revealed no evidence of uterine prolapse.

\section{Discussion}

Uterine prolapse in pregnancy is a rare condition. The main causes may be childbirth trauma, obstetric history of difficult deliveries or large babies, congenital connective tissue disorders, obesity, increased intraabdominal pressure, physiologic changes of pregnancy causing cervical elongation, hypertrophy and relaxation of the supportive ligaments (5). In this case uterine prolapse occurred in a first pregnancy and in the second trimester. Since there was no history of trauma or obstetric complications, we considered that this condition could be due to physiologic changes of pregnancy (hor- monal changes especially progesterone and relaxin effect causing growth and softening of the cervix). Another possible cause was congenital connective tissue disorders, but we could not attempt to do a serious diagnostic workup due to the patient's refusal.

The management strategies reported in the literature are conservative management, use of vaginal pessary, laparoscopic uterine suspension and concomitant cesarean hysterectomy with abdominal sacrocolpopexy (3, 5-7). Conservative management consists of gyneacological hygiene and bed rest in a slight Trandelenburg position and this is reported to be successful (5). In 1949, Klawans and Kanter advised continual use of the SmithHodge pessary throughout the pregnancy for women with late occurrence of prolapse (6). Vaginal pessaries can be obtained and applied easily. Vaginal discharge, odor, mucosal erosion and abrasions of vagina, urinary retention are common complications of vaginal pessaries (4). In this patient, we did not encounter any of this complications. Different types of vaginal pessary have been used but this management was reported as unsuccessful since pessaries frequently fall out after a few days. Contrary to the literature, this case was managed successfully with a pessary. The ring pessary and its size was perfectly fitted to the patient. The patient was taught how to use the pessary and she performed the proceedure perfectly. Thus, selection of pessary shape and its size and the patient's congruity to the treatment are the touchstones of success of this management. When conservative management fails and prolonged bed rest is impossible, another treatment choice may be laparoscopic uterine suspension during early pregnancy. However, this procedure should be performed in experienced hands since several failed laparoscopic uterine suspension cases have been reported (3). An alternative choice for women who have completed their family might be concomitant cesarean hysterectomy with abdominal sacrocolpopexy (7). Management strategies should be targeted to reduce complications of patient discomfort, urinary tract infections, urinary retention, cervical laceration, preterm labor, fetal and maternal infections and death. In this case we managed uterine prolapse successfully with a pessary and avoided all these complications.

In conclusion, the management and treatment of uterine prolapse in pregnancy should be individualized depending on the patient's preference. Vaginal pessary may be helpful to avoid complications of this condition and should be considered during patient counseling.

\section{Conflict of interest}

None declared

\section{References}

1. Mufarrij IK, Keettel WC. Prolapse of the uterus associated with pregnancy. Am J Obstet Gynecol. 1957; 73: 899-903.

2. Hill PS. Uterine prolapse complicating pregnancy. A case report. J Reprod Med 1984; 29: 631-3.

3. Matsumoto T, Nishi M, Yokota M, Ito M. Laparoscopic treatment of uterine prolapse during pregnancy. Obstet Gynecol 1999; 93: 849.

4. Te Linde's Operative Gynecology, 8. edition, Nonsurgical correction of defects, the use of vaginal support devices, Patricia J. Sulak. Chapter F, p.1082-3.

5. Guariglia L, Carducci B, Botta A, Ferrazzani S, Caruso A. Uterine prolapse in pregnancy.Gynecol Obstet Invest 2005; 60: 192-4.

6. Klawans AH, Kanter AE. Prolapse of the uterus and pregnancy. AmJ Obstet Gynecol. 1949; 57: 939-46.

7. Meydanli MM, Ustun Y, Yalcın OT. Pelvic organ prolapse complicating third trimester pregnancy. A case report. Gynecol Obstet Invest 2005; 61: 133-4. 